\title{
Granular corneal dystrophy type I
}

INSERM

\section{Source}

INSERM. (1999). Orphanet: an online rare disease and orphan drug data base. Granular corneal dystrophy type I. ORPHA:98962

Type I granular corneal dystrophy (GCDI) is a rare form of stromal corneal dystrophy (see this term) characterized by multiple small deposits in the superficial central corneal stroma, and progressive visual impairment, which may sometimes be severe. 